\title{
Pengembangan Sistem Pengukuran Kinerja Program Kemitraan di PKBL PT Sucofindo, Jakarta
}

\author{
Development of the System of Performance Measurement Partnership Program \\ in PCDP PT Sucofindo, Jakarta
}

\author{
Arifin Derajat Suryana ${ }^{1 \#}$, Sapta Raharja ${ }^{2 \#}$, dan Amiruddin Saleh ${ }^{3 \#}$ \\ ${ }^{1}$ PT Sucofindo (Persero) \\ Jl. Raya Pasar MInggu Kav. 34 Pancoran, Jakarta Selatan \\ ${ }^{2}$ Departemen Teknologi Industri Pertanian, Fakultas Teknologi Pertanian, Institut Pertanian Bogor \\ ${ }^{3}$ Departemen Komunikasi dan Pengembangan Masyarakat, Fakultas Ekologi Manusia, Institut Pertanian Bogor \\ "Jl. Kamper, Kampus IPB Dramaga, Bogor 16680
}

\begin{abstract}
ABSTRAK
Program kemitraan merupakan bagian dari kegiatan Program Kemitraan dan Bina Lingkungan (PKBL) sebagai bentuk tanggung jawab dari dana bergulir dan bagian dari keuntungannya. Sampai saat ini, dana bergulir program kemitraan mencapai Rp18,17 tilliun dan bertambah setiap tahun, yang membutuhkan manajemen yang baik dan pengukuran kinerja yang akurat. Saat ini kinerja program kemitraan PKBL diukur berdasarkan indikator efektivitas penyaluran dan tingkat kolektibilitas pengembalian pinjaman. Indikator tersebut dirasa belum dapat menggambarkan kinerja program secara keseluruhan, yang dapat menyebabkan disfungsi organisasi. Pengembangan dimulai dengan mengidentifikasi harapan pemangku kepentingan, kemudian menganalisa metode peringkat, klasifikasi, Logical Analysis Framework (LFA), analisis kesesuaian, Analytical Hierarchy Process (AHP), Focus Group Discussion (FGD), dan Objective Matrix (OMAX). Analisis menghasilkan delapan indikator baru, yaitu dilakukan survey bagi masyarakat pemangku kepentingan dan usaha kecil dengan sampel 30 responden untuk setiap kelompok pemangku kepentingan, sementara bagi karyawan stakeholder, manajemen, dan kementerian negara dilakukan sensus. Responden dipilih secara purposive. Hasil survey menunjukkan bahwa nilai kinerja PKBL PT Sucofindo Jakarta adalah 639,9, termasuk status kinerja baik.
\end{abstract}

Kata kunci: indikator kinerja, PKBL, sistem pengukuran kinerja

\section{ABSTRACT}

The partnership program is a part of the activity in the Partnership and Community Development Program (PCDP) as a form of responsibility by revolving funds and part of its profits. Up to now, revolving fund of the partnerships program has reached IDR 18.17 trillion and is growing every year, is need of good management and accurate performance measurement. Until now, the partnership program performance was measured by indicators of the effectiveness of distribution and level of collectibility loan repayment. There Indicators are still not able to describe the overall performance of the partnerships program, which may cause the dysfunction of organization. Development was started by identifying stakeholders' expectations, then analyzing the methods of ranking, classification, Logical Framework Analysis (LFA), suitability analysis, Analytical Hierarchy Process (AHP), Focus Group Discussion (FGD), and Objective Matrix (OMAX). The analysis resulted in eight new indicators, which conducted the survey for the community stakeholders and small businesses with a sample of 30 respondents for each group of stakeholders, while for stakeholders' employees, management, and state ministries was done census. Respondents selected purposively. The survey results show that the value of PCDP PT Sucofindo performance is 639.9, including a good performance status.

Key word: PCDP, performance measurement system, performance indicators

\footnotetext{
* Korespondensi:

Jl. Raya Pasar MInggu Kav. 34 Pancoran, Jakarta Selatan; e-mail: arifin@sucofindo.co.id
} 


\section{PENDAHULUAN}

Program Kemitraan dan Bina Lingkungan (PKBL) merupakan Program Pembinaan Usaha Kecil dan pemberdayaan kondisi lingkungan oleh Badan Usaha Milik Negara (BUMN) melalui pemanfaatan dana dari sebagian labanya. Jumlah penyisihan laba untuk pendanaan program maksimal 2\% dari laba bersih untuk Program Kemitraan dan maksimal $2 \%$ dari laba bersih untuk Program Bina Lingkungan (Kemeneg BUMN, 2007). Hasil kajian Hubeis (2010), bahwa UKM binaan dapat dikelompokkan atas UKM pra usaha dan usaha berjalan.

Peran PKBL BUMN diharapkan mampu mewujudkan 3 pilar utama pembangunan yang telah dicanangkan pemerintah dan merupakan janji politik kepada masyarakat, yaitu: (1) pengurangan jumlah pengangguran (pro-job); (2) pengurangan jumlah penduduk miskin (pro-poor); dan (3) peningkatan pertumbuhan ekonomi (progrowth).

Kegiatan PKBL dilaksanakan dengan berpedoman pada UU No. 19 tahun 2003 tentang BUMN dan Peraturan Menteri BUMN No. Per05/MBU/2007 yang menyatakan maksud dan tujuan pendirian BUMN tidak hanya mengejar keuntungan melainkan turut aktif memberikan bimbingan dan bantuan kepada pengusaha golongan ekonomi lemah, koperasi, dan masyarakat. Terdapat dua jenis program dalam PKBL yaitu Program Kemitraan, merupakan program untuk meningkatkan kemampuan usaha kecil agar menjadi tangguh dan mandiri melalui pemanfaatan dana dari bagian laba BUMN. Sementara Program Bina Lingkungan yaitu program untuk membentuk calon mitra binaan baru dan pemberdayaan kondisi sosial masyarakat oleh BUMN melalui pemanfaatan dana dari bagian laba BUMN (Kemeneg BUMN, 2007).

Sampai saat ini ada 141 BUMN yang telah melaksanakan program ini dan setiap tahunnya menggulirkan dana yang tidak sedikit, sampai tahun 2013 total dana yang dikeluarkan telah mencapai Rp25,76 trilliun (Kemeneg BUMN, 2011). Khusus program kemitraan dana yang dikelola adalah dana yang harus dikembalikan sehingga bergulir dari tahun ke tahun terus bertambah sehingga semakin lama semakin besar. Jumlah dana yang tidak kecil tersebut menuntut pengelolaan yang baik, sehingga dapat mencapai apa yang diharapkan dengan efisien dan efektif. Terlebih program kemitraan, dimana dana yang dikeluarkan merupakan dana bergulir yang harus dikembalikan. Hal ini memerlukan pengelolaan yang lebih rumit dan memiliki risiko tinggi. Salah satu cara untuk melihat apakah dana tersebut telah dikelola dengan baik adalah menilai kinerjanya. Kinerja yang baik menunjukkan bahwa pengelolaan berjalan dengan baik, sehingga memberikan manfaat maksimal kepada usaha kecil yang merupakan sasaran program ini.

Sampai saat ini, kinerja BUMN diukur berdasarkan Kepmen Negara BUMN No. KEP100/MBU/2002 tentang Penilaian Tingkat Kesehatan Badan Usaha Milik Negara, yang termasuk di dalamnya pengukuran kinerja PKBLnya. Dalam Keputusan Menteri tersebut yang dimuat pada lampiran II: 13/18, dinyatakan bahwa kinerja Pembinaan Usaha Kecil dan Koperasi (PUKK) (sekarang PKBL) dinilai berdasarkan indikator efektivitas penyaluran dan tingkat kolektibilitas pengembalian pinjaman. Dalam menyalurkan pembiayaan mikro kepada UMK, manajemen PUKK PT Sucofindo (Persero) memiliki pola/ bentuk tertentu dalam melakukan pembinaan kepada UMK, meliputi proses seleksi administrasi, survei lapangan, kelayakan usaha dan prospek usaha (Yusuf et al, 2006).

Penilaian kinerja tersebut di atas dirasakan belum cukup menggambarkan keberhasilan PKBL dalam melaksanakan tugasnya dan mencapai tujuannya. Dalam peraturan Menteri Pendayagunaan Aparatur Negara nomor: PER/20/M.PAN/11/ 2008, dikatakan bahwa instansi pemerintah belum disebut berkinerja sebelum dapat menunjukkan keberhasilan pencapaian outcome-nya.

Perusahaan PT Sucofindo merupakan salah satu BUMN yang melaksanakan program PKBL, telah melakukan penyaluran dana setiap tahunnya dan sampai dengan tahun ini telah mengeluarkan Rp247,15 milliar dan terus bertambah setiap tahunnya seperti terlihat dalam Tabel 1 . Dari latar belakang di atas, diperlukan pengembangan sistem pengukuran program kemitraan PKBL PT Sucofindo sebagai pemacu peningkatan kinerjanya sesuai dengan tujuan dan harapan stakeholder. Pengukuran kinerja hendak-nya dapat mencermikan seluruh kegiatan dan harapan stakeholder. Penelitian bertujuan: (1) Mengidentifikasi sistem pengukuran kinerja program kemitraan PKBL PT Sucofindo Jakarta; (2) Mengembangkan sistem pengukuran kinerja program kemitraan PKBL PT Sucofindo Jakarta; dan (3) Mengukur kinerja program kemitraan PKBL PT Sucofindo Jakarta dengan indikator pengukuran kinerja program kemitraan hasil pengembangan. 
Tabel 1. Realisasi dan anggaran penyaluran dana PKBL PT Sucofindo

\begin{tabular}{lccrrrrr}
\hline \multirow{1}{*}{ Program } & $\mathbf{7}$ & $\mathbf{7}$ & Tahun (Rp. Miliar) \\
\cline { 2 - 8 } & $\mathbf{2 0 0 7}$ & $\mathbf{2 0 0 8}$ & $\mathbf{2 0 0 9}$ & $\mathbf{2 0 1 0}$ & $\mathbf{2 0 1 1}$ & $\mathbf{2 0 1 2}$ ) & $\begin{array}{c}\text { Total } \\
\text { 1991 s/d 2012*) }\end{array}$ \\
\hline Kemitraan & 10,96 & 9,41 & 12,83 & 14,07 & 14,22 & 13,84 & 217,64 \\
Bina Lingkungan & 0,15 & 0,13 & 0,31 & 0,46 & 0,73 & 0,96 & 29,51 \\
\hline \multicolumn{1}{c}{ Jumlah } & 11,11 & 9,54 & 13,14 & 14,53 & 14,95 & 14,80 & 247,15 \\
\hline Sumber: PKBL PT. Sucofindo, 2007, 2008, 2009, 2010, 2011a.
\end{tabular}

\section{METODE PENELITIAN}

Lokasi kajian diadakan di PKBL PT Sucofindo Jakarta, Gedung Graha SUCOFINDO Jl. Raya Pasar Minggu Kav 34, Jakarta Selatan. Wilayah kerja PKBL PT Sucofindo Jakarta mencakup wilayah Jakarta, Bogor, Depok, Tangerang dan Bekasi dengan pengelolaan dana terbesar dan memiliki mitra binaan terbanyak dibanding dengan PKBL PT Sucofindo lainnya. Waktu penelitian dilaksanakan mulai bulan September 2012 sampai Januari 2013.

Pengumpulan data dilakukan dengan berbagai macam metode yang sesuai dengan kegiatan dan kebutuhannya. Terdapat lima kegiatan utama dalam penelitian ini, yaitu (1) Identifikasi sistem pengukuran kinerja program kemitraan PKBL saat ini, (2) Studi literatur, (3) Identifikasi harapan stakeholder kepada PKBL, (4) Pengembangan sistem pengukuran kinerja program kemitraan PKBL dan (5) Pengukuran kinerja program kemitraan PKBL PT Sucofindo Jakarta.

Penentuan contoh dengan metode purposive sampling, dimana contoh diambil dengan alasan tertentu. Contoh diambil seara sengaja dengan argumentasi ilmiah (Eriyatno, 2007). Wawancara dilakukan terhadap responden yang ditentukan sebagai key person dari PKBL, yaitu kepala dan manajer dalam organisasi formal PKBL PT Sucofindo. Metode dokumenter dilakukan dengan penelaahan pada dokumen dan peraturan kinerja yang berlaku saat ini, seperti buku pedoman PKBL PT Sucofindo dan surat keputusan Meneg BUMN tentang Penilaian Tingkat Kesehatan BUMN. Kegiatan identifikasi ini menghasilkan informasi sistem pengukuran kinerja program kemitraan PKBL PT Sucofindo yang berlaku saat ini.

\section{Identifikasi Harapan Stakeholder kepada PKBL}

Dari penelitian yang telah dilakukan seperti Pengukuran Kinerja Corporate Social Responsibility (CSR) di PT Semen Gresik, Tbk (Rahmadhani, 2011), merupakan awal dari pengembangan sistem kinerja dilakukan dengan identifikasi stakeholder want and need. Hal ini sesuai dengan perkembangan fokus perusahaan yang harus mengakomodir semua kebutuhan dan keinginan stakeholder. Pada kegiatan ini identifikasi harapan stakeholder diawali dengan pembuatan kuesioner yang didasari oleh kegiatan satu dan dua di atas. Kuesioner terdiri dari pertanyaan tertutup dan terbuka untuk menampung pendapat lain dari stakeholder. Pertanyaan dalam kuesioner mengacu kepada sistem pengukuran kinerja program kemitraan PKBL saat ini, peraturan yang ada dan metode sistem pengukuran organisasi yang telah dibuat para pakar.

Kuesioner dibuat untuk masing-masing kelompok stakeholder. Sebelum kuesioner digunakan dilakukan uji validitas dan reliabilitas. Uji validasi dan reliabilitas dilakukan kepada responden yang berbeda dengan responden penelitian. Pemilihan responden untuk pengujian kuesioner adalah secara purposif, dimana responden dipilih sesuai kriteria. Kriteria dimaksud adalah orang yang mengerti PKBL dan UKM (Usaha Kecil Menengah). Uji validitas dan reliabilitas dilakukan untuk kuesioner masyarakat dan kuesioner usaha kecil dengan responden masing-masing 30 orang.

Metode analisis data yang digunakan adalah:

\section{Logical Framework Analysis (LFA)}

Metode LFA dilakukan dengan bantuan dikusi dengan pakar dan dalam penelitian ini digunakan untuk menganalisis data harapan stakeholder yang diperoleh dari survei dengan kuesioner sehingga didapat indikator untuk mengukur pencapaian harapan tersebut.

\section{Analytical Hierarchy Process (AHP)}

AHP memungkinkan pengguna memberikan nilai bobot relatif dari suatu kriteria majemuk secara intuitif, yaitu melakukan perbandingan berpasangan (pairwise comparisons). Selanjutnya menentukan cara konsisten untuk mengubah perbandingan berpasangan menjadi suatu himpunan bilangan yang mempresen- 
tasikan prioritas relatif dari setiap kriteria dan alternatif (Saaty dalam Marimin, 2005).

Kriteria dan alternatif dinilai melalui perbandingan berpasangan. Menurut Saaty dalam Marimin (2005), untuk berbagai persoalan, skala 1-9 adalah skala terbaik dalam mengekspresikan pendapat, dengan nilai dan definisi pendapat kualitatif sebagai berikut:

Nilai 1 : kriteria/alternatif A sama dengan kriteria/alternatif B

Nilai 3 : A sedikit lebih penting dari B

Nilai 5 : A jelas lebih penting dari B

Nilai 7 : A sangat jelas lebih penting dari B

Nilai 9 : A mutlak lebih penting dari B

3. Focus Group Discussion (FGD)

FGD dimaksudkan untuk menghindari pemaknaan yang salah dalam suatu penelitian terhadap fokus masalah yang diteliti. Kehadiran orang lain menjadi "penolong" terhadap kelemahan pemikiran pribadi (Bungin, 2007). Proses FGD melibatkan berbagai pihak yang dipandang dapat memberi sumbangan pemikiran terhadap persoalan yang didiskusikan. Penentuan peserta FGD berkaitan dengan beberapa hal, yaitu keahlian/kepakaran, pengalaman, pribadi terlibat, tokoh otoritas, dan masyarakat (Bungin, 2007).

\section{Objective Matrix (OMAX)}

Dengan menggunakan OMAX, pihak manajemen dapat dengan mudah menentukan kriteria apa yang menjadi ukuran. Pada akhirnya pihak manajemen dapat mengetahui organisasi yang menjadi tanggung jawabnya berdasarkan bobot dan skor untuk setiap kriteria. Penentuan kriteria penilaian dilakukan dengan pengembangan skor/angka. Skor OMAX terletak pada rentang 0-10, dimana nilai nol menunjukkan bahwa kinerja sangat jauh di bawah target (kinerja buruk) dan nilai 10 kinerja terbaik atau menunjukkan kinerja telah mencapai target dan jauh melampaui target. Nilai satu sampai dengan sembilan merupakan nilai interpolasi antara nilai nol dan 10. Penentuan target dan nilai pada skor OMAX dilakukan dengan FGD.

\section{HASIL DAN PEMBAHASAN}

PT Superintending Company of Indonesia (PT. Sucofindo) adalah perusahaan inspeksi pertama di Indonesia. Sebagian besar sahamnya, yaitu 95\% dikuasai Negara dan 5\% milik Societe Generale de Surveillance Holding SA (SGS). PT Sucofindo ber- diri pada 22 Oktober 1956, dimana bisnisnya bermula dari kegiatan perdagangan terutama komoditas pertanian dan kelancaran arus barang dan pengamanan devisa negara dalam perdagangan ekspor-impor. Seiring dengan perkembangan kebutuhan dunia usaha, Sucofindo melakukan langkah kreatif dan menawarkan inovasi jasa-jasa baru berbasis kompetensinya. Melalui studi analisis dan inovasi, dilakukan diversifikasi jasa sehingga lahirlah jasa-jasa warehousing dan forwarding, analytical laboratories, industrial and marine engineering, dan fumigation and industrial hygiene. Sampai saat ini telah memiliki 152 jenis jasa yang diklasifikasikan dalam lima jenis yaitu: Inspeksi dan Audit, Pengujian dan Analisa, Layanan Sertifikasi, Layanan Pelatihan, dan Layanan Konsultasi. Keanekaragaman jasa ini dikemas secara terpadu, jaringan kerja laboratorium, cabang dan titik layanan di berbagai kota di Indonesia. Sampai saat ini PT Sucofindo mempunyai 34 cabang dan 17 Laboratorium yang tersebar di seluruh Indonesia. Jumlah karyawan tetap PT Sucofindo adalah 3.678 orang yang tesebar di seluruh cabang dan berasal dari berbagai strata pendidikan dan disiplin ilmu.

\section{Sistem Pengukuran Kinerja PT Sucofindo}

Sampai saat ini sistem pengukuran kinerja PKBL merupakan bagian dari sistem penilaian kesehatan BUMN yang dicantumkan dalam keputusan Kemeneg BUMN nomor Kep-100/ MBU/2002. Dalam keputusan menteri tersebut, sistem pengukuran kinerja PKBL masuk ke dalam penilaian pada aspek administrasi. Akan tetapi sejak tahun 2007 telah terdapat rencana pengembangan sistem pengukuran kinerja program kemitraan. Hal ini dapat dilihat pada Peraturan Menega BUMN nomor PER-05/MBU/2007 tentang Program Kemitraan BUMN dengan Usaha Kecil dan Program Bina Lingkungan yaitu pada Bab IX kinerja program kemitraan Pasal 30, yaitu (1) Kinerja Program Kemitraan merupakan salah satu indikator penilaian tingkat kesehatan BUMN Pembina, (2) Perhitungan kinerja Program Kemitraan akan diatur kemudian oleh Menteri.

Dalam perkembangan sistem pengukuran kinerja organisasi seperti yang dikemukakan Wibisono (2011) bahwa fokus pengelolaan perusahaan saat ini bukan lagi hanya pada kepentingan pihak tertentu, tetapi berkembang untuk kepentingan semua pihak (stakeholder). Sebagai contoh dalam penerapan evaluasi sistem pengukuran kinerja di Bank Tabungan Negara (BTN) cabang Solo (Putri, 2008), menggunakan 
balance scorecard untuk mengakomodir aspek non keuangan. Meskipun BTN merupakan lembaga keuangan, disadari bahwa pengukuran kinerja yang hanya berfokus pada aspek keuangan saja untuk mengukur kinerja eksekutif tidak lagi memadai. Pengukuran kinerja dengan sistem ini menyebabkan orientasi perusahaan hanya pada keuntungan jangka pendek dan cenderung mengabaikan kelangsungan hidup perusahaan dalam jangka panjang. Apalagi bank merupakan perusahaan jasa seperti halnya PT Sucofindo, dimana pelanggan merupakan komponen penting dalam kelangsungan bisnisnya.

\section{Identifikasi Harapan Stakeholder kepada PKBL}

\section{Harapan Stakeholder}

Survei harapan stakeholder dilakukan terhadap responden yang dipilih secara purposive. Responden untuk stakeholder masyarakat berjumlah 31 orang yang terdiri dari pakar, praktisi dan orang yang dipandang mengetahui tentang PKBL BUMN. Stakeholder usaha kecil 32 responden yang terdiri dari pengusaha kecil mitra binaan BUMN dan bukan mitra binaan. Stakeholder manajemen PKBL PT Sucofindo seluruhnya menjadi responden, yaitu berjumlah empat responden. Stakeholder karyawan PKBL PT Sucofindo Jakarta seluruhnya menjadi responden (tujuh responden), sedangkan stakeholder Kementerian BUMN yang menangani PKBL berjumlah tujuh responden.

\section{Klasifikasi Harapan Stakeholder}

Terdapat beberapa harapan yang sama dari kelompok stakeholder berbeda dengan proses klasifikasi, maka harapan yang sama tersebut disatukan. Pada harapan stakeholder Kemeneg BUMN terdapat dua harapan pada posisi ranking empat. Hasil klasifikasi melahirkan enam aspek harapan, yaitu aspek keuangan, pelayanan, proses operasional, administrasi, kemampuan organisasi dan karyawan. Pengelompokan aspek ini berdasarkan studi literatur, dimana beberapa referensi menyebutkan aspek-aspek sangat erat keterkaitannya. Pada aspek keuangan terdapat empat harapan stakeholder untuk program kemitraan. Aspek pelayanan merupakan aspek yang sebaiknya ada dalam organisasi non profit, apalagi organisasi pemerintah yang melayani masyarakat. Hal ini terbukti dari survei aspek ini diharapkan oleh stakeholder PKBL.

Aspek pelayanan memiliki satu harapan stakeholder untuk dikembangkan, karena sesuai tujuan organisasi, yaitu melayani masyarakat.
Terdapat aspek proses operasional yang diharapkan memiliki Standard Operating Procedure (SOP) di semua kegiatan termasuk SOP pengawasan dan pembinaan. Ketiga SOP dapat disatukan menjadi SOP pengelolaan PKBL BUMN. Harapan stakeholder agar PKBL lebih banyak melakukan sosialisasi merupakan cerminan keingintahuan stakeholder tentang program PKBL BUMN. Aspek administrasi terdiri dari tertib administrasi dan tuntutan adanya Rencana Kerja dan Angaran (RKA) setiap tahun. Aspek kemampuan organisasi (kapabilitas) merupakan harapan stakeholder kepada PKBL untuk membuktikan kemampuannya menghasilkan keluaran berupa keberhasilan pembinaan dan bebas Kolusi, Korupsi dan Nepotisme (KKN). Aspek karyawan juga merupakan harapan dari stakeholder yang terdiri dari penilaian kinerja lebih adil dengan metode $360^{\circ}$, dimana penilaian kinerja karyawan dilakukan bukan hanya oleh atasannya, tetapi juga oleh rekan kerja dan bawahannya. Dari penelitian Sudharma (2002), Handayani et al (2005), serta Nurmianto dan Siswanto (2006) tentang penilaian kinerja, ditemukan bahwa terdapat variasi (perbedaan) kinerja pegawai, baik individu maupun kelompok yang dijadikan obyek penelitian.

\section{Pengembangan Sistem Pengukuran Kinerja PKBL}

\section{Penentuan Indikator Kinerja Program Kemitraan}

Identifikasi menghasilkan harapan stakeholder yang menjadi target untuk dipenuhi. Pemenuhan harapan stakeholder ini terlihat dan terdefinisi secara logika dalam LFA yang disebut juga logframe. Harapan akan diterjemahkan ke dalam akibat (impact) yang terjadi sebagai pertimbangan untuk menentukan hasil/tujuan. Tujuan jelas memudahkan penentuan indikator sebagai alat ukur untuk melihat keberhasilan pencapaian hasil/tujuan. Menurut Asniwaty (2009), salah satu parameter keberhasilan suatu perusahaan dari sudut pandang CSR adalah mengedepankan prinsip moral dan etis yakni menggapai hasil terbaik tanpa merugikan kelompok masyarakat lainnya, dengan demikian perusahaan yang bekerja dengan dengan prnsip moral dan etis akan memberikan manfaat yang besar bagi masyarakat.

Logframe aspek keuangan menghasilkan empat indikator yang dapat menjadi alat ukur harapannya. Dari empat indikator tersebut terdapat dua indikator yang selama ini digunakan untuk mengukur kinerja PKBL. Logframe aspek keuangan dapat dilihat pada Tabel 2. Plafon 
pinjaman merupakan indikator untuk melihat apakah PKBL dapat memenuhi harapan Stakeholder yang menghendaki perubahan dari aturan yang ada saat sekarang, yaitu maksimal plafon pinjaman Rp60 juta rupiah. Batasan ini dipandang dapat membatasi pengembangan usaha kecil yang memerlukan pinjaman lebih besar dari Rp60 juta rupiah, sedangkan usaha kecil hanya dapat meminjam pada satu PKBL, sehingga untuk mendapatkan pinjaman lebih besar dari Rp60 juta sangat sulit.

Di dalam aturan, baik undang-undang maupun aturan pemerintah tidak terdapat persyaratan jaminan untuk pinjaman dengan PKBL, tetapi pada pelaksanaannya beberapa PKBL BUMN mensyaratkan. Hal ini dilakukan karena belajar dari pengalaman penyebab dari pengembalian yang kurang lancar yang salah satunya karena kurangnya rasa tanggungjawab mitra binaan terhadap uang yang dipinjam. Mitra binaan merasa seolah-olah pinjaman merupakan bantuan pemerintah yang tidak wajib dikembalikan. Hal ini menjadi dilema bagi PKBL, padahal harapan stakeholder meniadakan jaminan menjadi berat, tetapi harus dilaksanakan sebagai komitmen untuk memuaskan seluruh stakeholder.

Efektivitas penyaluran dana adalah jumlah dana yang disalurkan dibagi dengan jumlah dana yang tersedia dikali 100\%. Jumlah dana tersedia adalah seluruh dana pembinaan yang tersedia dalam tahun bersangkutan yang terdiri atas saldo awal, pengembalian pinjaman, setoran sisa pembagian laba yang diterima dalam tahun bersangkutan (termasuk alokasi dana PUKK BUMN lain, jika ada), pendapatan bunga dari pinjaman PUKK. Jumlah dana yang disalurkan adalah seluruh dana yang disalurkan kepada usaha kecil dan koperasi dalam tahun bersang- kutan yang terdiri dari hibah dan bantuan pinjaman, termasuk dana penjaminan (dana yang dialokasikan untuk menjamin pinjaman usaha kecil dan koperasi kepada Lembaga Keuangan).

Tingkat kolektibilitas penyaluran pinjaman adalah rata-rata tertimbang kolektibilitas pinjaman PUKK dibagi dengan Jumlah pinjaman yang disalurkan dikali $100 \%$. Rataan tertimbang kolektibilitas pinjaman PUKK adalah perkalian antara bobot kolektibilitas (\%) dengan saldo pinjaman untuk masing-masing kategori kolektibilitas sampai dengan periode akhir tahun buku yang bersangkutan. Dalam aspek pelayanan harapan stakeholder adalah kepuasan masyarakat terhadap PKBL. Dengan beberapa pertimbangan, sudah selayaknya organisasi pelayanan masyarakat harus berorientasi kepada pelayanan yang memuaskan pelanggan, sehingga indikator yang dimunculkan adalah tingkat kepuasan pelanggan. Logframe aspek pelayanan dapat dilihat pada Tabel 3.

Tingkat kepuasan pelanggan dimaksud adalah hasil survei kepuasan pelanggan yang dilakukan kepada mitra binaan dan mantan mitra binaan. Hasil survei kepuasan pelanggan diharapkan bisa menjadi alat ukur kepuasan pelanggan PKBL. Dalam hal ini, aspek proses operasional memuat harapan stakeholder yang menuju pada hasil semakin banyak masyarakat yang mengerti program PKBL. Untuk mencapai hasil tersebut, PKBL diharapkan melakukan sosialisasi dan membuat SOP untuk kegiatankegiatannya. Kegiatan sosialisasi bisa dilakukan dengan berbagai jenis kegiatan, seperti langsung memberikan informasi pada usaha kecil melalui asosiasinya, penyuluhan dan memberikan informasi melalui media masa (TV, radio, surat kabar, majalah dll). Untuk memenuhi harapan adanya

Tabel 2. Logframe aspek keuangan

\begin{tabular}{llll}
\hline Harapan & Akibat & Hasil & Indikator \\
\hline $\begin{array}{l}\text { Plafon pinjaman ke PKBL yang } \\
\text { lebih besar dari saat ini } \leq \text { Rp60 } \\
\text { juta) }\end{array}$ & $\begin{array}{l}\text { Usaha UKM dapat lebih } \\
\text { berkembang }\end{array}$ & $\begin{array}{l}\text { Pinjaman dapat lebih } \\
\text { besar dari Rp60 juta }\end{array}$ & Plafon Pinjaman \\
$\begin{array}{l}\text { Pinjaman kepada PKBL tidak } \\
\text { menggunakan jaminan }\end{array}$ & $\begin{array}{l}\text { UKM tidak memiliki } \\
\text { jaminan untuk menjadi mitra } \\
\text { binaan }\end{array}$ & $\begin{array}{l}\text { Mitra binaan tidak harus } \\
\text { menyerahkan jaminan }\end{array}$ & Penggunaan Jaminan \\
$\begin{array}{l}\text { Penyaluran pinjaman usaha } \\
\text { kecil efektif pada PKBL }\end{array}$ & $\begin{array}{l}\text { Lebih banyak usaha kecil } \\
\text { yang terbantu }\end{array}$ & $\begin{array}{l}\text { Lebih banyak dana } \\
\text { pinjaman terserap }\end{array}$ & $\begin{array}{l}\text { Efektivitas } \\
\text { Penyaluran }\end{array}$ \\
$\begin{array}{l}\text { pengembat kolektibilitas } \\
\text { kecil tinggi }\end{array}$ & $\begin{array}{l}\text { Lebih banyak dana pinjaman } \\
\text { Lang terkumpul }\end{array}$ & $\begin{array}{l}\text { pebinjaman ban dana } \\
\text { disalurkan }\end{array}$ & $\begin{array}{l}\text { Tingkat } \\
\text { Kolektibilitas }\end{array}$ \\
\hline
\end{tabular}


SOP untuk semua kegiatan, maka PKBL harus membuat SOP sesuai alur proses kegiatan mulai dari penerimaan usulan pinjaman/hibah sampai pengawasan dan pembinaan usaha kecil. Logframe aspek operasional dapat dilihat pada Tabel 4.

Aspek yang keempat adalah aspek administrasi, dimana PKBL diharapkan dalam melakukan kegiatannya dapat mengadministrasikannya dengan baik dan memiliki RKA. Tertib administrasi akan mengakibatkan semua kegiatan dapat dibuktikan dengan berkas yang lengkap alur proses teratur dan mampu telusur. Indikator hasil logframe untuk memenuhi harapan PKBL tertib administrasi yaitu berkas lengkap sesuai SOP dan permintaan berkas dapat cepat dipenuhi. Adanya RKA setiap tahunnya dibuktikan dengan dimilikinya laporan kegiatan dan RKA pada tahun pengukuran kinerja. Logframe aspek administrasi dapat dilihat pada Tabel 5.

Harapan stakeholder pada aspek kemampuan organisasi telah menuntut PKBL memiliki kemampuan mengembangkan mitra binaan dan melakukannya dengan baik tanpa adanya KKN. Logframe aspek kemampuan organisasi terdapat pada Tabel 6.

Tabel 3. Logframe aspek pelayanan

\begin{tabular}{llll}
\hline Harapan & Akibat & Hasil & Indikator \\
\hline $\begin{array}{l}\text { Pelayanan pelanggan } \\
\text { PKBL yang baik }\end{array}$ & $\begin{array}{l}\text { Kegiatan berjalan } \\
\text { dengan baik }\end{array}$ & $\begin{array}{l}\text { Kepuasan pelanggan } \\
\text { terpenuhi }\end{array}$ & $\begin{array}{l}\text { Tingkat Kepuasan } \\
\text { Pelanggan }\end{array}$ \\
\hline
\end{tabular}

Tabel 4. Logframe aspek proses operasional

\begin{tabular}{llll}
\hline Harapan & Akibat & Hasil & Indikator \\
\hline $\begin{array}{l}\text { PKBL lebih banyak } \\
\text { melakukan sosialisasi } \\
\text { ke masyarakat }\end{array}$ & $\begin{array}{l}\text { Peluang pengembangan usaha } \\
\text { UKM lebih besar }\end{array}$ & $\begin{array}{l}\text { Semakin banyak } \\
\text { masyarakat mengerti } \\
\text { program PKBL BUMN }\end{array}$ & Kegiatan sosialisasi \\
$\begin{array}{l}\text { Adanya SOP untuk } \\
\text { pengelolaan PKBL }\end{array}$ & $\begin{array}{l}\text { Kemudahan pelaksanaan } \\
\text { kegiatan }\end{array}$ & $\begin{array}{l}\text { Kegiatan tertib sesuai } \\
\text { SOP }\end{array}$ & SOP Kegiatan \\
& - Pencegahan penyimpangan & & \\
\hline
\end{tabular}

Tabel 5. Logframe aspek administrasi

\begin{tabular}{llll}
\hline Harapan & Akibat & Hasil & Indikator \\
\hline $\begin{array}{l}\text { PKBL yang tertib } \\
\text { administrasi }\end{array}$ & $\begin{array}{l}\text { Mampu telusur } \\
\text { Mudah pengawasan }\end{array}$ & $\begin{array}{l}\text { Alur proses kegiatan } \\
\text { cepat, aman dan } \\
\text { terkendali }\end{array}$ & $\begin{array}{l}\text { - Berkas lengkap } \\
\text { sesuai SOP }\end{array}$ \\
& & $\begin{array}{l}\text { Permintaan berkas } \\
\text { dapat cepat dipenuhi }\end{array}$ \\
$\begin{array}{l}\text { Rencana Kerja dan } \\
\text { Anggaran (RKA) PKBL } \\
\text { harus ada setiap tahunnya }\end{array}$ & $\begin{array}{l}\text { Tersedianya informasi } \\
\text { tentang program kerja } \\
\text { Mudah melaksanakan } \\
\text { kegiatan }\end{array}$ & $\begin{array}{l}\text { Memiliki informasi } \\
\text { program kerja dan } \\
\text { pedoman kegiatan } \\
\text { tahunan }\end{array}$ & RKA \\
& & & \\
\hline
\end{tabular}

Tabel 6. Logframe aspek kemampuan organisasi

\begin{tabular}{llll}
\hline Harapan & Akibat & Hasil & Indikator \\
\hline $\begin{array}{l}\text { Keberhasilan pembinaan } \\
\text { PKBL sehingga usaha kecil } \\
\text { meningkat usahanya }\end{array}$ & $\begin{array}{l}\text { Mitra binaan } \\
\text { berkembang }\end{array}$ & $\begin{array}{l}\text { Peningkatan skala } \\
\text { usaha mitra binaan }\end{array}$ & $\begin{array}{l}\text { Peningkatan parameter skala } \\
\text { usaha mitra binaan }\end{array}$ \\
PKBL bebas KKN & $\begin{array}{l}\text { Tidak ada kerugian } \\
\text { negara/masyarakat }\end{array}$ & $\begin{array}{l}\text { Adanya komitmen } \\
\text { manajemen untuk } \\
\text { bebas KKN }\end{array}$ & $\begin{array}{l}\text { - Kampanye anti KKN } \\
\text { penyimpangan KKN }\end{array}$ \\
\hline
\end{tabular}


Tabel 7. Logframe aspek karyawan

\begin{tabular}{llll}
\hline Harapan & Akibat & Hasil & Indikator \\
\hline $\begin{array}{l}\text { Penilaian kinerja karyawan } \\
\text { PKBL menggunakan sistem } \\
360^{\circ}\end{array}$ & $\begin{array}{l}\text { Kinerja } \\
\text { meningkat }\end{array}$ & $\begin{array}{l}\text { Karyawan termotivasi } \\
\text { dan semangat kerja } \\
\text { meningkat }\end{array}$ & $\begin{array}{l}\text { SOP penilaian } \\
\text { karyawan } 360^{\circ}\end{array}$ \\
$\begin{array}{l}\text { Kepuasan karyawan PKBL } \\
\text { yang tinggi }\end{array}$ & $\begin{array}{l}\text { Kinerja } \\
\text { meningkat }\end{array}$ & Tidak adanya keluhan & $\begin{array}{l}\text { Tingkat kepuasan } \\
\text { karyawan }\end{array}$ \\
$\begin{array}{l}\text { Ketersediaan pelatihan untuk } \\
\text { karyawan sesuai tugasnya }\end{array}$ & $\begin{array}{l}\text { Kegiatan } \\
\text { sesuai target }\end{array}$ & $\begin{array}{l}\text { Keterampilan karyawan } \\
\text { meningkat }\end{array}$ & Pelatihan karyawan \\
\hline
\end{tabular}

Keberhasilan pembinaan dapat dilihat dari peningkatan parameter skala usaha mitra binaan, dimana apabila parameter skala usaha meningkat, maka pembinaan dapat dikatakan berhasil. Parameter skala usaha mitra binaan dimaksud adalah parameter yang mampu memberikan gambaran usaha mitra binaan seperti jumlah aset, omzet, jumlah penjualan, laba, dll. Penentuan parameter yang digunakan untuk menilai perkembangan usaha dilakukan sesuai kesepakatan antara manajemen dengan pihak yang berkepentingan. Harapan bebas KKN dimaksudkan agar tidak ada kerugian Negara/masyarakat yang disebabkan oleh kegiatan yang mementingkan diri pribadi atau golongan tertentu. Tekad untuk menjalankan kegiatan bebas KKN harus ditunjukkan adanya komitmen manajemen yang diwujudkan berupa adanya upaya kampaye anti KKN kepada para karyawan/manajemen PKBL dan adanya aturan yang jelas tentang penyimpangan KKN.

Aspek karyawan memuat keinginan karyawan pada PKBL untuk lebih memperhatikan karyawan, baik dari segi karir maupun segi kompetensinya. Akibat dari harapan karyawan terpenuhi, diharapkan dapat meningkatkan kinerja, sehingga mencapai target. Logframe aspek karyawan dapat dilihat pada Tabel 7.

Hasil yang diharapkan adalah motivasi karyawan meningkat, tidak adanya keluhan karyawan dan keterampilan karyawan meningkat. Untuk memenuhi harapan dan pencapaian hasil tersebut maka pengukuran dilakukan dengan melihat adanya SOP penilaian karyawan dengan sistem $360^{\circ}$, tingkat kepuasan karyawan dan pelatihan karyawan.

Dalam memprakarsai keterampilan pelatihan dan program pengembangan dalam organisasi, kebutuhan untuk memastikan pegawai mengikuti perubahan teknologi dan sosial dalam rangka untuk mempertahankan tenaga kerja yang kompeten dan produktif adalah suatu hal yang penting (Jinabhai, 2005).

\section{Analisis Kesesuaian}

Indikator-indikator tersebut dilakukan analisis kesesuaian, yaitu menganalisa apakah indikator-indikator tersebut dapat memenuhi kriteria-kriteria indikator, seperti specific (S), measurable $(\mathrm{M})$, achievable $(\mathrm{A})$, realistic $(\mathrm{R})$, timely $(\mathrm{T})$, continuously improve $(\mathrm{C})$, relevan $(\mathrm{Rv})$, prioritas (P) dan layak (L).

Semua indikator merupakan indikator yang jelas dan specific, memiliki batasan terukur dan dapat disesuaikan dengan kemampuan, sehingga dapat dicapai, berasal dari harapan stakeholder, dapat diberi batasan waktu merupakan indikator yang dapat terus-menerus dikembangkan, sangat berhubungan dengan kinerja, merupakan prioritas dan indikator tersebut harus diperhatikan untuk memenuhi harapan stakeholder. Hasil analisis menunjukkan bahwa semua indikator memenuhi kriteria yang disyaratkan (sesuai).

\section{Pemilihan Indikator Kinerja Utama}

Dari analisis data hasil survei didapatkan 16 indikator sebagai pedoman pengukuran untuk mencapai harapan stakeholder. Dari 16 indikator tersebut dipilih 10 Indikator Kinerja Utama (IKU). Pemilihan dilakukan dengan menggunakan metode AHP, sehingga didapat alternatif pilihan ranking pada Tabel 8 .

Hasil analisis AHP memberikan petunjuk urutan ranking dari 1-16 dengan nilai Consistency Ratio (CR) 0,044. Nilai CR yang diperoleh masih berada di bawah 0,1 sehingga hasil dinyatakan konsisten (dapat digunakan). Dari hasil indikator kinerja utama diambil 10 ranking teratas, sehingga untuk indikator kinerja utamanya adalah (1) Peningkatan parameter skala usaha mitra binaan; (2) Tingkat kepuasan pelanggan; (3) Kegiatan sosialisasi; (4) Efektivitas penyaluran; (5) Tingkat kolektibilitas; (6) SOP kegiatan; (7) Laporan 
kegiatan dan RKA; (8) Kampanye anti KKN; (9) Aturan yang jelas untuk penyimpangan KKN; (10) Tingkat kepuasan karyawan.

Tabel 8. Hasil analisis peringkat dengan metode AHP

\begin{tabular}{clc}
\hline Ranking & \multicolumn{1}{c}{ Indikator } & $\begin{array}{c}\text { Nilai } \\
\text { Prioritas }\end{array}$ \\
\hline 1 & Peningkatan parameter skala & 0,195 \\
& $\begin{array}{l}\text { usaha mitra binaan } \\
2\end{array}$ & Tingkat kepuasan pelanggan \\
3 & Kegiatan sosialisasi & 0,155 \\
4 & Efektivitas penyaluran & 0,120 \\
5 & Tingkat kolektibilitas & 0,109 \\
6 & SOP kegiatan & 0,083 \\
7 & Laporan kegiatan dan RKA & 0,069 \\
8 & Kampanye anti KKN & 0,056 \\
9 & Aturan yang jelas untuk & 0,047 \\
& penyimpangan KKN & 0,039 \\
10 & Tingkat kepuasan karyawan & 0,031 \\
11 & Pelatihan karyawan & 0,023 \\
12 & Berkas lengkap sesuai SOP & 0,021 \\
13 & Permintaan berkas dapat cepat & 0,017 \\
& dipenuhi & \\
14 & Penggunaan jaminan & 0,014 \\
15 & Plafon pinjaman & 0,011 \\
16 & SOP penilaian karyawan 360 & 0,009 \\
\hline
\end{tabular}

\section{Pembobotan Indikator Kinerja Utama}

Pembobotan dilakukan dengan perhitungan proporsional nilai prioritas hasil AHP yang sebelumnya terdiri atas 16 indikator dan setelah dipilih 10 ranking teratas menjadi 10 indikator kinerja utama. Hasil perhitungan pembobotan disajikan dalam Tabel 9.

\section{Dokumen Sumber Verifikasi}

Pada saat dilakukan pengukuran kinerja dengan indikator-indikator tersebut diperlukan sumber informasi yang menyatakan secara resmi tentang seberapa besar nilai indikator tersebut. Keberadaan sumber informasi tersebut merupakan bukti autentik dari pada pengukuran kinerja dari organisasi. Sumber informasi umumnya dinyatakan dalam dokumen resmi yang diterbitkan oleh lembaga resmi, baik organissi itu sendiri maupun pihak eksternal. Dokumen sumber verifikasi pada perancangan sistem pengukuran kinerja disesuaikan dengan dokumen yang sudah ada. Dokumen sumber verifikasi untuk indikator pengukuran kinerja PKBL PT Sucofindo dapat dilihat pada Tabel 10.

Tabel 9. Hasil pembobotan

\begin{tabular}{clc}
\hline No. & \multicolumn{1}{c}{ Indikator } & Bobot \\
\hline 1 & Peningkatan parameter skala usaha & 22 \\
& mitra binaan & \\
2 & Tingkat kepuasan pelanggan & 17 \\
3 & Kegiatan sosialisasi & 13 \\
4 & Efektivitas penyaluran & 12 \\
5 & Tingkat kolektibilitas & 9 \\
6 & SOP kegiatan & 8 \\
7 & Laporan kegiatan dan RKA & 6 \\
8 & Kampanye anti KKN & 5 \\
9 & Aturan yang jelas untuk & 4 \\
& penyimpangan KKN & 4 \\
10 & Tingkat kepuasan karyawan & 100 \\
\hline
\end{tabular}

Form A dalam prosedur survei lapangan yang dilakukan untuk melakukan verifikasi proposal pengajuan pinjaman memuat hasil survei berupa informasi tentang profile usaha kecil mulai dari alamat, pemiliki, aset, omzet, laba, jumlah karyawan dan lainnya, sedangkan

Tabel 10. Dokumen sumber verifikasi

\begin{tabular}{|c|c|c|}
\hline No. & Indikator & Dokumen Sumber Verifikasi \\
\hline 1 & $\begin{array}{l}\text { Peningkatan parameter skala usaha } \\
\text { mitra binaan }\end{array}$ & $\begin{array}{l}\text { Form A dalam prosedur survei lapangan dan form } \mathrm{C} \\
\text { dalam prosedur monitoring lapangan }\end{array}$ \\
\hline 2 & Tingkat kepuasan pelanggan & Dokumen hasil survei kepuasan pelanggan \\
\hline 3 & Kegiatan sosialisasi & Laporan Program Kemitraan dan Bina Lingkungan \\
\hline 4 & Efektifitas penyaluran & Laporan Program Kemitraan dan Bina Lingkungan \\
\hline 5 & Tingkat kolektibilitas & Laporan Program Kemitraan dan Bina Lingkungan \\
\hline 6 & SOP kegiatan & Dokumen SOP \\
\hline 7 & Laporan kegiatan dan RKA & Laporan Kegiatan dan Dokumen RKA \\
\hline 8 & Kampanye anti korupsi & Dokumen hasil pengamatan tim penilai \\
\hline 9 & $\begin{array}{l}\text { Aturan yang jelas untuk } \\
\text { penyimpangan } \mathrm{KKN}\end{array}$ & Doukumen peraturan \\
\hline 10 & Tingkat kepuasan karyawan & Dokumen hasil survei kepuasan karyawan \\
\hline
\end{tabular}


form C pada prosedur monitoring lapangan merupakan laporan kunjungan yang dilakukan dalam rangka pembinaan yang memuat informasi perkembangan usaha yang sedang berjalan. Dokumen hasil survei pelanggan merupakan laporan hasil survei pelanggan yang dilakukan setiap akhir tahun untuk mengetahui kualitas pelayanan organisasi.

Sampai saat ini, PKBL selalu menyampaikan laporan PKBL ke Kementerian BUMN. Laporan tersebut memuat laporan kegiatan, penyaluran dan pengembalian pinjaman. Di samping itu terdapat pula prosedur yang menjadi acuan dari kegiatan dalam PKBL, sehingga bisa menjadi acuan indikator SOP kegiatan. Menjelang akhir tahun, PKBL juga membuat RKA yang berisi laporan kegiatan dan prediksi biaya untuk tahun berjalan. Indikator aturan yang jelas untuk penyimpangan $\mathrm{KKN}$ dapat diverifikasi dengan ada atau tidaknya peraturan perusahaan yang berkaitan dengan hal tersebut. Tingkat kepuasan karyawan dilihat dari dokumen survei kepuasan karyawan yang merupakan hasil survei kepuasan karyawan yang dilakukan setiap akhir tahun.

\section{Cara Perhitungan Indikator}

Pada saat pelaksanaan pengukuran kinerja dilakukan perhitungan terhadap masing-masing indikator. Perhitungan dilakukan untuk mendapatkan skor yang akan dikalikan dengan bobot, sehingga menjadi nilai pengukuran kinerja indikator tersebut. Penetapan nilai indikator disetarakan dengan skor dilakukan dengan pendapat pakar melalui FGD. Perhitungan dilakukan sebagai berikut:

1. Peningkatan Parameter Skala Usaha Mitra Binaan

Peningkatan parameter skala usaha adalah perbedaan nilai parameter skala usaha yang terdapat dalam form C (Laporan Monitoring Perkembangan Usaha Kecil dan Koperasi (UKK) dalam prosedur monitoring lapangan) atau form A hasil survei proposal pinjaman tahap selanjutnya, yang dibandingkan dengan data awal sebelum diberikan pinjaman yang terdapat dalam form A hasil survei dalam prosedur survei. Adapun skala usaha dimaksud adalah nilai dari aset, omzet, dan laba. Masing-masing diberi bobot seimbang yaitu aset 7,3 omzet 7,3 dan laba 7,4. Perhitungan dilakukan terhadap usaha kecil yang masa pinjamannya selesai pada tahun pengukuran. Dilakukan pengambilan contoh terhadap usaha kecil secara acak pada tiap-tiap jenis usaha (random sampling). Peningkatan parameter skala usaha merupakan rataan peningkatan parameter skala usaha dari contoh usaha kecil yang diambil. Skor penilaian adalah nol untuk tidak ada peningkatan skala usaha dan 10 untuk skala usaha meningkat $46 \%$ atau lebih. Penetapan $46 \%$ untuk skor 10 didasari dari pendapat pakar dan data historis yang menunjukkan bahwa kenaikan skala usaha $46 \%$ merupakan kenaikan tinggi. Untuk skor penilaian di antara 1-9 merupakan interpolasi dari peningkatan nol sampai dengan $46 \%$.

2. Tingkat Kepuasan Pelanggan

Tingkat kepuasan pelanggan dihitung dari hasil survei kepuasan pelanggan yang dilakukan di akhir tahun terhadap mitra binaan, mantan mitra binaan dan obyek bina lingkungan. Tingkat kepuasan pelanggan disesuaikan dengan skor mulai dari 0-10, dimana nol merupakan nilai terburuk dari tingkat kepuasan pelanggan dan 10 merupakan tingkat kepuasan terbaik.

3. Kegiatan Sosialisasi

Kegiatan sosialisasi yang dimaksud adalah kegiatan menjelaskan program kemitraan dan bina lingkungan kepada masyarakat atau kelompok masyarakat melalui berbagai jenis kegiatan. Untuk penilaian skor kegiatan sosialisasi dihitung frekuensinya dalam tahun pengukuran. Skor nol merupakan skor yang diberikan, apabila dalam satu tahun tidak melakukan kegiatan sosialisasi dan skor 10 diberikan, apabila kegiatan sosialisasi dilakukan lebih dari 10 kegiatan.

4. Efektivitas Penyaluran

Efektivitas penyaluran dihitung dari laporan tahunan, dimana terdapat jumlah penyaluran pinjaman kepada mitra binaan dalam tahun laporan yang dibandingkan dengan jumlah dana tersedia di tahun tersebut. Skor nol untuk penyaluran $<80 \%$ dan skor 10 untuk penyaluran $>90 \%$. Untuk skor diantara satu sampai dengan sembilan merupakan inter-polasi dari nilai $80-90 \%$. Penetapan skor tersebut mengacu pada keputusan Meneg BUMN Nomor: Kep-100/MBU/2002 tentang Penilaian Tingkat Kesehatan BUM.

5. Tingkat Kolektibilitas

Tingkat kolektibilitas dihitung dari laporan tahunan dimana terdapat jumlah penerimaan dari pinjaman dibandingkan dengan jumlah dana yang disalurkan dalam tahun pelaporan. Skor nol untuk tingkat pengembalian $<10 \%$ dan skor 10 untuk tingkat pengembalian > 
$70 \%$. Untuk skor di antara satu sampai dengan sembilan merupakan interpolasi dari nilai 10 sampai dengan $70 \%$. Penetapan skor tersebut mengacu pada keputusan Meneg BUMN Nomor: Kep-100/MBU/2002 Tentang Penilaian Tingkat Kesehatan BUMN.

6. SOP kegiatan

Terdapat 10 kegiatan sesuai dengan alur proses yang dipandang penting untuk dibuatkan SOP, termasuk pengawasan dan pembinaan kepada usaha kecil oleh PKBL. SOP tersebut menjadi pedoman penilaian skor dimana skor 0 akan diberikan pada PKBL yang tidak memiliki sama sekali SOP dan skor 10 diberikan pada PKBL yang memiliki SOP lengkap. Masing-masing SOP memiliki nilai yang sama, yaitu satu. SOP tersebut adalah:

a. Prosedur Permohonan Pinjaman

b. Prosedur Survei Lapangan

c. Prosedur Evaluasi Kelayakan Usaha

d. Prosedur Penyaluran Pinjaman

e. Prosedur Monitoring Lapangan

f. Prosedur Monitoring Pengembalian Angsuran

g. Prosedur Kerjasama dengan Pihak ke Tiga

h. Prosedur Penilaian Peningkatan Skala Usaha Mitra Binaan

i. Prosedur Pembinaan Mitra Binaan

j. Prosedur Pengawasan Internal

7. Laporan Kegiatan dan RKA

Laporan kegiatan memuat realisasi rencana kerja dan anggaran tahun penilaian. RKA memuat proyeksi realisasi tahun penilaian dan rencana kerja satu tahun ke depan. Skor nol diberikan bila tidak memiliki laporan kegiatan dan RKA, sedangkan skor 10 diberikan bila keduanya memuat sesuai dengan peraturan yang ada.

8. Kampanye Anti KKN

Pemberian skor komitmen PKBL untuk bebas KKN dilihat dari adanya kegiatan kampanye di lingkungan kerja PKBL, seperti adanya pernyataan bersama, slogan anti KKN, adanya kegiatan sosialisasi pengawasan melekat dan pembinaan mental karyawan. Skor nol untuk tidak adanya kampanye seperti di atas dan skor 10 untuk adanya kampanye lengkap dan komprehensif, sedangkan skor 1-9 diberikan untuk kegiatan yang belum lengkap dan komprehensif (penentuan skor diserahkan pada penilai).
9. Aturan yang jelas untuk penyimpangan KKN

Komitmen untuk anti KKN di PKBL salah satunya diwujudkan dengan adanya aturan tentang penyimpangan yang disebabkan oleh praktek KKN. Perhitungan skor untuk indikator ini adalah adanya aturan tentang penyimpangan karena KKN diberi skor 10 dan apabila belum ada aturan tersebut, diberi skor nol.

10. Tingkat kepuasan karyawan

Tingkat kepuasan karyawan dihitung dari hasil survei kepuasan karyawan yang dilakukan diakhir tahun terhadap seluruh karyawan PKBL. Tingkat kepuasan karyawan disesuaikan dengan skor mulai dari 0-10, dimana nol merupakan nilai terburuk dari tingkat kepuasan karyawan dan 10 merupakan tingkat kepuasan terbaik. Untuk skor 1-9 menyesuaikan dengan nilai tingkat kepuasan karyawan hasil survei.

\section{Penentuan Kriteria Penilaian}

Dari cara perhitungan tersebut, maka didapat tabel OMAX sebagai pedoman penilaian kinerja PKBL. Hasil penentuan kriteria penilaian dengan OMAX disajikan pada Tabel 11. Baris "Pencapaian" pada Tabel 11 merupakan tempat menyajikan penilaian tahun sebelumnya. Baris "Pencapaian" tersebut berfungsi untuk menilai peningkatan kinerja dari tahun sebelumnya dengan menghitung indeks prestasi tahun penilaian yaitu nilai kinerja tahun penilaian dibagi dengan nilai kinerja tahun lalu. Baris "Target" pada Tabel 11 merupakan sasaran kinerja berupa skor yang akan dicapai yang telah ditetapkan pada awal tahun penilaian. Baris "Target" tersebut berfungsi untuk menghitung pencapaian target pada tahun penilaian. Baris "Skor" pada Tabel 11 merupakan tempat menyajikan skor sesuai hasil penilaian saat tahun penilaian.

Baris "Bobot" pada Tabel 11 merupakan hasil pembobotan indikator dengan metode AHP. Baris "Nilai" merupakan hasil perkalian antara skor dan bobot. Baris "Nilai Target" adalah hasil perkalian antara target dan bobot. Baris "\% Pencapaian Target" adalah persentase perbandingan antara nilai dan nilai target. Baris "Status Kinerja" merupakan komitmen manajemen dan pemilik organisasi yang ditetapkan dalam Rapat Umum Pemegang Saham (RUPS) pada awal tahun penilaian. Status kinerja dapat disepakati diambil dari nilai atau dari persentase pencapaian target. 
Tabel 11. Kriteria Penilaian dengan OMAX

\begin{tabular}{|c|c|c|c|c|c|c|c|c|c|c|c|c|}
\hline \multirow[b]{2}{*}{ INDIKATOR } & \multicolumn{3}{|c|}{1} & \multirow[b]{2}{*}{2} & \multirow[b]{2}{*}{3} & \multirow[b]{2}{*}{4} & \multirow[b]{2}{*}{5} & \multirow[b]{2}{*}{6} & \multirow[b]{2}{*}{7} & \multirow[b]{2}{*}{8} & \multirow[b]{2}{*}{9} & \multirow[b]{2}{*}{10} \\
\hline & $\begin{array}{c}\text { Asset } \\
(\%)\end{array}$ & $\begin{array}{c}\text { Omzet } \\
(\%)\end{array}$ & $\begin{array}{c}\text { Laba } \\
(\%)\end{array}$ & & & & & & & & & \\
\hline
\end{tabular}

PENCAPAIAN

TARGET

SCOR

$\begin{array}{ccccccccccccc}\geq 46 & \geq 46 & \geq 46 & 10 & 10 & >90 \% & >70 \% & 10 & 10 & 10 & 10 & 10 & 10 \\ 41-45 & 41-45 & 41-45 & 9 & 9 & 89 \% & 64 \% & 9 & 9 & 9 & 9 & 9 & 9 \\ 36-40 & 36-40 & 36-40 & 8 & 8 & 88 \% & 58 \% & 8 & 8 & 8 & 8 & 8 & 8 \\ 31-35 & 31-35 & 31-35 & 7 & 7 & 87 \% & 52 \% & 7 & 7 & 7 & 7 & 7 & 7 \\ 26-30 & 26-30 & 26-30 & 6 & 6 & 86 \% & 46 \% & 6 & 6 & 6 & 6 & 6 & 6 \\ 21-25 & 21-25 & 21-25 & 5 & 5 & 85 \% & 40 \% & 5 & 5 & 5 & 5 & 5 & 5 \\ 16-20 & 16-20 & 16-20 & 4 & 4 & 84 \% & 34 \% & 4 & 4 & 4 & 4 & 4 & 4 \\ 11-15 & 11-15 & 11-15 & 3 & 3 & 83 \% & 28 \% & 3 & 3 & 3 & 3 & 3 & 3 \\ 6-10 & 6-10 & 6-10 & 2 & 2 & 82 \% & 22 \% & 2 & 2 & 2 & 2 & 2 & 2 \\ 1-5 & 1-5 & 1-5 & 1 & 1 & 81 \% & 16 \% & 1 & 1 & 1 & 1 & 1 & 1 \\ <0 & <0 & <0 & 0 & 0 & <80 \% & <10 \% & 0 & 0 & 0 & 0 & 0 & 0\end{array}$

$\begin{array}{cccccccccccccc}\text { BOBOT } & 7,3 & 7,3 & 7,4 & 17 & 13 & 12 & 9 & 8 & 6 & 5 & 4 & 4 \\ \text { NILAI } & & & & & & & & & & \end{array}$

\section{NILAI TARGET}

$\%$ PENC. TARGET

STATUS KINERJA

\author{
Keterangan: \\ $1=$ Peningkatan parameter skala usaha mitra \\ binaan \\ $2=$ Tingkat kepuasan pelanggan \\ $3=$ Kegiatan sosialisasi \\ $4=$ Efektifitas penyaluran
}

\section{Pengukuran Kinerja Program Kemitraan PKBL PT Sucofindo Jakarta}

Kesesuaian Sistem Pengukuran Kinerja Hasil Pengembangan dengan Kondisi PKBL PT Sucofindo saat ini

Sistem pengukuran kinerja hasil pengembangan memuat 10 indikator utama, dimana dua diantaranya merupakan indikator yang selama ini digunakan untuk mengukur kinerja PKBL, yaitu efektivitas penyaluran dan tingkat kolekbilitas. Terdapat delapan indikator baru yang belum pernah dilakukan pengukuran selama ini di PKBL PT Sucofindo. Untuk pengukuran kinerja dengan 10 indikator tersebut diperlukan dokumen sumber verifikasi. Dokumen sumber verifikasi ada yang sudah tersedia pada kegiatan PKLB PT Sucofindo, ada pula yang belum. Ketersedian dokumen verifikasi pada PKBL PT Sucofindo disajikan pada Tabel 12.

\author{
$5=$ Tingkat kolektibilitas \\ $6=$ SOP kegiatan \\ 7 = Laporan kegiatan dan RKA \\ $8=$ Kampanye anti korupsi \\ 9 = Aturan yang jelas untuk penyimpangan KKN \\ $10=$ Tingkat kepuasan karyawan
}

Dari Tabel 12 terlihat ada tiga dokumen sumber verifikasi yang belum tersedia, sehingga untuk melakukan penilaian kinerja perlu adanya upaya mengadakan dokumen tersebut. Dokumen hasil survei kepuasan pelanggan belum dimiliki, karena belum pernah dilakukan survei kepuasan pelanggan maka sebelum penilaian perlu dilakukan survei kepuasan pelanggan. Dokumen hasil pengamatan tim penilai diadakan pada saat pengukuran kinerja dilakukan. Untuk dokumen hasil survei kepuasan karyawan, seperti halnya dokumen hasil survei kepuasan pelanggan yaitu belum pernah dilakukan survei kepuasan karyawan, sehingga perlu dilakukan survei kepuasan karyawan terlebih dahulu. Di samping itu beberapa parameter yang terdapat dalam dokumen sama, seperti kegiatan sosialisasi, efektifitas penyaluran dan tingkat kolektibilitas terdapat pada laporan program kemitraan dan bina lingkungan yang dibuat setiap akhir tahun. 
Tabel 12. Ketersediaan dokumen sumber verifikasi

\begin{tabular}{|c|c|c|c|c|}
\hline No. & Indikator & Dokumen Sumber Verifikasi & Tersedia & $\begin{array}{c}\text { Belum } \\
\text { Tersedia }\end{array}$ \\
\hline 1 & $\begin{array}{l}\text { Peningkatan parameter skala } \\
\text { usaha mitra binaan }\end{array}$ & Form $\mathrm{A}$ dan form $\mathrm{C}$ & $\sqrt{ }$ & \\
\hline 2 & Tingkat kepuasan pelanggan & $\begin{array}{l}\text { Dokumen hasil survei kepuasan } \\
\text { pelanggan }\end{array}$ & & $\sqrt{ }$ \\
\hline 3 & Kegiatan sosialisasi & Laporan PKBL & $\sqrt{ }$ & \\
\hline 4 & Efektifitas penyaluran & Laporan PKBL & $\sqrt{ }$ & \\
\hline 5 & Tingkat kolektibilitas & Laporan PKBL & $\sqrt{ }$ & \\
\hline 6 & SOP kegiatan & Dokumen SOP & $\sqrt{ }$ & \\
\hline 7 & Laporan kegiatan dan RKA & Laporan kegiatan dan dokumen RKA & $\sqrt{ }$ & \\
\hline 8 & Kampanye anti KKN & $\begin{array}{l}\text { Dokumen hasil pengamatan tim } \\
\text { penilai }\end{array}$ & & $\sqrt{ }$ \\
\hline 9 & $\begin{array}{l}\text { Aturan yang jelas untuk } \\
\text { penyimpangan } \mathrm{KKN}\end{array}$ & Dokumen peraturan & $\sqrt{ }$ & \\
\hline 10 & Tingkat kepuasan karyawan & $\begin{array}{l}\text { Dokumen hasil survei kepuasan } \\
\text { karyawan }\end{array}$ & & $\sqrt{ }$ \\
\hline
\end{tabular}

\section{Pengukuran Kinerja Program Kemitraan PKBL}

Pengukuran dilakukan untuk periode tahun 2011, karena untuk tahun 2012 laporan program kemitraan dan bina lingkungan belum dibuat. Pengukuran dilakukan dengan beberapa asumsi, yaitu untuk indikator kepuasan pelanggan dan kepuasan karyawan tidak dilakukan survey, akan tetapi diasumsikan kepuasan pelanggan dan karyawan berada ditingkat sedang (skor lima). Hal ini dilakukan karena keterbatasan biaya dan waktu untuk melakukan survei dengan skor lima karena selama ini tidak tercatat adanya keluhan dari pelanggan maupun karyawan (cukup memadai). Menurut Asropi (2007), jumlah indikator kinerja yang dipilih sebagai indikator kinerja utama ini biasanya tidak banyak, namun demikian hasil pengukuran melalui indikator tersebut dapat digunakan untuk menilai tingkat keberhasilan organisasi dalam mencapai tujuan dan sasaran yang telah ditetapkan. Hasil pengukuran masing-masing indikator sebagai berikut:

1. Peningkatan Parameter Skala Usaha Mitra Binaan

Perhitungan peningkatan parameter skala usaha dilakukan dengan mengambil data skala usaha yaitu aset, omzet dan laba pada dokumen form A pada tiap-tiap arsip dokumen usaha kecil yang mengajukan proposal pinjaman dan form A pada saat usaha kecil mengajukan kembali untuk tahap kedua. Dalam hal ini peningkatan skala usaha dapat pula dilihat pada data yang terdapat pada form C, yaitu form hasil kunjungan lapangan. Tetapi tidak semua berkas dokumen usaha kecil memiliki form C, disebabkan karena pada PKBL PT Sucofindo yang dikunjungi dalam pembinaan belum dilakukan dengan teratur, baik waktu maupun pelaksanaannya.

Terdapat 150 usaha kecil yang telah selesai masa pinjamannya pada tahun 2011/2012. Untuk perhitungan peningkatan parameter skala usaha diambil contoh 30 usaha kecil dari berbagai jenis usaha. Pengambilan contoh dilakukan secara acak dari 150 dokumen usaha kecil yang ada. Perhitungan dilakukan dengan membandingkan aset, omzet, dan laba sebelum usaha kecil memperoleh pinjaman dan sesudah pinjaman selesai dibayarkan.

Dari hasil perhitungan peningkatan skala usaha omzet rataan adalah 35\%. Skor peningkatan skala usaha omzet dengan nilai perhitungan 35\% adalah tujuh. Dari hasil perhitungan peningkatan skala usaha laba rataan adalah $79 \%$. Skor untuk indikator peningkatan skala usaha laba dengan nilai 79\% adalah 10 .

2. Tingkat Kepuasan Pelanggan

Tingkat kepuasan pelanggan diasumsikan dalam katagori sedang atau skor lima. Hal ini karena selama ini belum pernah ada keluhan dari pelanggan yang diterima, sedangkan di sisi lain belum pernah ada survei kepuasan palanggan.

3. Kegiatan Sosialisasi

Selama ini PKBL PT Sucofindo belum pernah melaksanakan sosialisasi tentang PKBL, baik secara langsung ke usaha kecil, melalui asosiasinya, penyuluhan maupun melalui media masa. Tidak ada dokumen pendukung bahwa PKBL PT Sucofindo telah melakukan sosialisasi, maka skor indikator kegiatan sosialisasi nol. 
4. Efektivitas Penyaluran

Efektivitas penyaluran dana tahun 2011 sebesar $97,47 \%$

Rumus: Jumlah dana yang disalurkan x 100\% Jumlah dana yang tersedia

\section{: $\underline{\operatorname{Rp} 15.181 .183 .160 \times 100 \%}$ Rp15.574.458.071}

Skor indikator efektivitas penyaluran dengan nilai $97,47 \%$ adalah 10 .

5. Tingkat kolektibilitas

Tingkat kolektibilitas pinjaman

Keterangan:

$\begin{array}{lrcrr}\text { Lancar } & 15.886 .823 .926 & \times 100 \% & = & 15.886 .823 .926 \\ \text { Kurang } & 2.444 .241 .290 & \text { X 75\% } & = & 1.833 .180 .968 \\ \text { Lancar } & & & & \\ \text { Ragu-ragu } & 1.135 .443 .819 & \text { X 25\% } & = & 283.860 .955 \\ \text { Macet } & 4.908 .452 .601 & \text { X0\% } & = & 0 \\ \text { Jumlah } & 24.374 .961 .636 & & = & 18.003 .865 .848\end{array}$

$\underline{\text { Rata-rata tertimbang kolektibilitas pinjaman }}$ PUKK x 100\%

Jumlah pinjaman yang disalurkan

$$
\text { : } \frac{\operatorname{Rp} 18.003 .865 .848 \times 100 \%}{\operatorname{Rp} 24.374 .961 .636}
$$$$
\text { : 73,86\% }
$$

Skor indikator tingkat kolektibilitas dengan nilai $73,86 \%$ adalah 10 .

6. SOP Kegiatan

Dari dokumen yang ada, PKBL PT Sucofindo baru memiliki tujuh prosedur, yaitu prosedur permohonan pinjaman, prosedur survei lapangan, prosedur evaluasi kelayakan usaha, prosedur penyaluran pinjaman, prosedur monitoring lapangan, prosedur monitoring pengembalian angsuran, dan prosedur kerjasama dengan pihak ketiga. Untuk prosedur prosedur penilaian peningkatan skala usaha mitra binaan, prosedur pembinaan dan prosedur pengawasan internal belum dimiliki, maka skor indikator SOP kegiatan untuk PKBL PT Sucofindo adalah tujuh.

7. Laporan Kegiatan dan RKA

Hasil pengamatan terdapat laporan kegiatan tahun 2011 yang memuat realisasi RKA tahun 2011 dan terdapat pula RKA tahun 2012. Skor untuk indikator ini 10.

8. Kampanye Anti Korupsi

Pada PKBL PT Sucofindo belum terlihat adanya kegiatan kampaye anti korupsi dilingkuangan kerjanya. Belum memiliki moto, belum adanya slogan-slogan dan juga belum adanya penyuluhan/pelatihan khusus untuk memperkuat mental karyawan. Skor untuk indikator kampanye anti korupsi adalah nol.

9. Aturan yang Jelas untuk Penyimpangan KKN

Terdapat aturan yang jelas untuk penyimpangan $\mathrm{KKN}$ yang dilakukan oleh oknum manajemen maupun karyawan PKBL PT Sucofindo. Aturan tersebut tertuang pada Peraturan Disiplin Pegawai (PDP) perusahaan PT Sucofindo. Skor untuk indikator aturan yang jelas untuk penyimpangan KKN adalah 10 .

10. Tingkat kepuasan karyawan

Tingkat kepuasan karyawan diasumsikan dalam katagori sedang atau skor lima, dikarenakan selama ini belum pernah ada keluhan dari karyawan dan di sisi lain belum pernah ada survei kepuasan karyawan.

Baris Pencapaian tidak dapat diisi karena belum adanya pengukuran pada tahun sebelumnya. Begitu juga baris "Target" pada awal tahun belum dilakukan penentapan target. Baris "Status Kinerja" diasumsikan menggunakan nilai maksimum 1000 sebagai kinerja sangat baik dan nol sebagai kinerja sangat buruk, sehingga diperoleh status kinerja: 0-200: sangat buruk; 201-400: buruk; 401-600: sedang; 601-800: baik; 801-1.000: sangat baik. Hasil pengukuran menunjukkan nilai kinerja PKBL PT Sucofindo tahun 2011 mencapai 639,9, sehingga masuk ke dalam status kinerja baik. indeks prestasi belum dapat dihitung, karena tahun lalu belum ada penilaian kinerja seperti ini.

\section{KESIMPULAN}

Saat ini sistem pengukuran kinerja PKBL PT Sucofindo mengacu pada surat keputusan Meneg BUMN nomor KEP-100/MBU/2002 tentang Penilaian Tingkat Kesehatan BUMN, yaitu atas indikator efektivitas penyaluran pinjaman dan tingkat kolektibilitas pengembalian. Kedua indikator belum dapat menggambarkan kinerja PKBL secara keseluruhan, sehingga dapat menyebabkan disfungsi organisasi yang merugikan semua pihak.

Pengembangan sistem pengukuran kinerja program kemitraan menghasilkan delapan indikator baru, sehingga seluruh indikator berjumlah 10 dengan bobot dan nilai maksimum/minimum yang disetarakan dengan skor nol sampai 10 dalam OMAX. Sebagai acuan penilaian ditetapkan dokumen sumber verifikasi terhadap tiap-tiap indikator tersebut, agar penilaian mudah dilakukan dan hasil akhir nilai total kinerja diklasifi- 
kasikan atas nilai 0-200 (kinerja sangat buruk), 201-400 (kinerja buruk), 401-600 (kinerja sedang), 601-800 (kinerja baik), dan 801-1000 (kinerja sangat baik).

Sistem pengukuran kinerja hasil pengembangan dapat diimplementasikan pada PKBL PT. Sucofindo Jakarta dan menghasilkan nilai 639,9 untuk kinerja tahun 2011 sehingga berstatus kinerja baik dengan asumsi skor indikator kepuasan pelanggan dan karyawan masing-masing lima.

\section{DAFTAR PUSTAKA}

Asniwaty, B. 2009. Evaluasi Pelaksanaan Corporate Social Responsibility PT Pupuk Kaltim. JURNAL EKSIS, 6 (1): 1266-1273.

Asropi. 2007. Membangun Key Performance Indikator Lembaga Pelayanan Publik. Jurnal Manajemen Pembangunan No. 57/I/Tahun XVI. Institut Teknologi Sepuluh November. Surabaya.

Bungin, B. 2007. Penelitian Kualitatif. Prenada Media Group. Jakarta.

Eriyanto. 2007. Teknik Sampling Analisis Opini Publik. LKiS Yogyakarta.

Jinabhai, DC. 2005. New Challenges For South African Development and TrainingLinkages To Emperical Research. Public Personnel Management, ABI/INFORM Research, Spring 2005, 34 (1): 85-101.

Handayani, NU. H. Santoso, S. Rochmawati. 2005. Perancangan Sistem Pengukuran Kinerja Menggunakan Metoda Performance Prims. TEKNOIN, 10 (4): 295-303.

Hubeis, M. 2010. Kajian Pembinaan, Pengembangan dan Pengawasan UKM Binaan PT Sucofindo. Jurnal Manajemen IKM, 5 (1): 1-11.

[Kemeneg BUMN] Kementerian Negara Badan Usaha Milik Negara. 2007. Peraturan Menteri Negara BUMN, nomor PER-05/ MBU/2007, tentang Program Kemitraan Badan Usaha Milik Negara dengan Usaha Kecil dan Program Bina Lingkungan. Kementerian Negara BUMN. Jakarta.

2011. Peraturan Menteri

Negara BUMN nomor Per - 03/MBU/2011 tentang Pedoman Penyusunan Laporan Kinerja di Lingkungan Kementerian Badan Usaha Milik Negara. Kementerian Negara BUMN. Jakarta.
Marimin. 2005. Teknik dan Aplikasi Pengambilan Keputusan Kriteria Majemuk. Grasindo. Jakarta.

Nurmianto, E, Siswanto, dan Nurhadi. 2006. Perancangan Penilaian Kinerja Karyawan Berdasarkan Kompetensi Spencer dengan Metode Analitical Hierarchy Process. Jurnal Teknik Industri, 8 (1): 40-53.

Putri D.P. 2008. Analisis Pengukuran Kinerja Perusahaan dengan Konsep Balanced Scorecard Studi Kasus Pada PT Bank Tabungan Negara Cabang Solo. Universitas Muhammadiyah. Surakarta.

Rahmadhani, A. 2011. Perancangan Model Pengukuran Kinerja Corporate Social Responsibility Berdasarkan Integrasi Model Pengukuran Kinerja PRISM dan Indikator Kinerja GRI (Studi Kasus: PT. Semen Gresik, Tbk). Institut Teknologi Sepuluh November (ITS). Surabaya.

PKBL PT Sucofindo. 2007. Laporan Program Kemitraan dan Bina Lingkungan PT Sucofindo Tahun 2007. PT Sucofindo, Jakarta.

2008. Laporan Program Kemitraan dan Bina Lingkungan PT Sucofindo Tahun 2008. PT. Sucofindo, Jakarta.

2009. Laporan Program Kemitraan dan Bina Lingkungan PT Sucofindo Tahun 2009. PT Sucofindo, Jakarta. 2010. Laporan Program Kemitraan dan Bina Lingkungan PT Sucofindo Tahun 2010. PT Sucofindo, Jakarta.

2011. Laporan Program Kemitraan dan Bina Lingkungan PT Sucofindo Tahun 2011. PT Sucofindo, Jakarta.

Sudharma, I Nyoman. 2002. Kajian Terhadap Kinerja dan Pengembangan Karyawan Operasional Hotel Bali Hyatt. Tesis pada Program Pascasarjana Magister Manajemen Universitas Udayana.

Wibisono, D. 2011. Manajemen Kinerja Korporasi dan Organisasi. Erlangga, Jakarta.

Yusuf, Y., M. Hubeis dan H. Hardjomidjojo. 2006. Model Penyaluran Kredit kepada Usaha Mikro dan Kecil Berdasarkan Karakter dan Kapasitas (Kasus Unit Kemitraan dan Bina Lingkungan PT Sucofindo). Jurnal MPI, 1 (2): 1-12. 